\title{
Revision of the genus Pseudotocinclus (Siluriformes: Loricariidae: Hypoptopomatinae), with descriptions of two new species
}

\author{
Adriana Kazue Takako*, Claudio Oliveira*, and Osvaldo Takeshi Oyakawa**
}

\begin{abstract}
The genus Pseudotocinclus is revised and two new species are described: Pseudotocinclus juquiae from the Ribeira de Iguape basin and Pseudotocinclus parahybae from the rio Paraíba do Sul basin. The presence of a small naked area on the snout tip distinguishes $P$. tietensis from P. parahybae and P. juquiae, which have the snout tip covered with small platelets. In addition, P. tietensis has four transverse dark-brown bands on the dorsum coalesced with the midlateral stripe instead of three, as in its congeners. Pseudotocinclus juquiae is distinguished from its congeners by having the orbital ring very prominent and conspicuous, a characteristic not found in P. tietensis or P. parahybae. These three species also differ from their congeners by meristic and morphometric data. Comments on the past connection of Ribeira de Iguape, Paraíba do Sul and upper Tietê basins are presented.

O gênero Pseudotocinclus é revisado e duas novas espécies são descritas: Pseudotocinclus juquiae da bacia do rio Ribeira de Iguape e Pseudotocinclus parahybae da bacia do rio Paraíba do Sul. A presença de uma pequena área nua na ponta do focinho distingue $P$. tietensis de P. parahybae e $P$. juquiae, que apresentam a ponta do focinho coberta por pequenas placas. Além disso, $P$. tietensis tem quatro bandas transversas marrom-escuras na região dorsal do corpo, fundidas com uma barra mediana lateral, ao invés de três bandas, como nas demais espécies. Pseudotocinclus juquiae distingue-se de suas congêneres pela presença de um anel orbital muito proeminente e conspícuo não observado em P. tietensis ou P. parahybae. As três espécies também diferem quanto a seus dados morfométricos e merísticos. São apresentados comentários a respeito das conexões pretéritas das bacias dos rios Ribeira de Iguape, alto Tietê e Paraíba do Sul.
\end{abstract}

Key words: Taxonomy, South America, Biogeography, Brazil, Coastal drainages.

\section{Introduction}

Among the 680 or more species of Neotropical Siluriformes of the family Loricariidae, the members of the subfamily Hypoptopomatinae are probably best recognized as belonging to a natural group (Schaefer, 1991, 2003). These fishes are small to moderate in size (30-130 $\mathrm{mm}$ in standard length) and share a similar overall adult physiognomy, distinctive for the Loricariidae. Most are moderately elongated, a few are strongly depressed, and all share a peculiar morphology of the pectoral-fin skeleton (Schaefer, 1991). The Hypoptopomatinae includes 79 species arranged in 16 genera (Schaefer, 2003), broadly distributed in South American freshwaters. The subfamily is divided into two tribes, Hypoptopomatini and Otothyrini, with the genus Pseudotocinclus being a member of the latter (Schaefer, 1991, 1998). Until now, Pseudotocinclus has included only one species, P. tietensis (Ihering, 1907), considered endemic to the headwaters of the upper rio Tietê basin (Britski \& Garavello, 1984).

The genus Pseudotocinclus was previously treated as valid (Britski \& Garavello, 1984; Schaefer, 1991) and distinguished from other Hypoptopomatinae by having a caudal peduncle that is nearly square in cross section, 26 or more plates along the lateral line, a dorsally positioned eye, an exposed preopercle, an abdomen covered with numerous small platelets, and a naked snout tip. However, in our study, we found that a naked snout tip is found in only one of the species. Like other hypoptopomatines, Pseudotocinclus is primarily herbivorous, more commonly found at or near the upper portion of the water column, in close association with sub-surface structures provided by submerged tree branches, aquatic macrophytes, and terrestrial grass blades growing along creek margins and extending into the water (Schaefer, 1998).

\footnotetext{
*Departamento de Morfologia, Instituto de Biociências, Universidade Estadual Paulista, 18618-000 Botucatu, SP, Brazil. e-mail: adrianaktakako@yahoo.com.br, claudio@ibb.unesp.br

**Museu de Zoologia da Universidade de São Paulo, Seção de Peixes, Caixa Postal 42494, 04218-970 São Paulo, SP, Brazil. e-mail: oyakawa@usp.br
} 
Recent collecting efforts revealed the presence of Pseudotocinclus in tributaries of the Ribeira de Iguape basin (Bizerril \& Lima, 2000) and the rio Paraíba do Sul basin. In the present paper, specimens found in the different basins were comparatively analyzed and two new species are described.

\section{Material and Methods}

Specimens examined belong to the following institutions: Museu de Zoologia da Universidade de São Paulo, São Paulo (MZUSP); Laboratório de Biologia e Genética de Peixes, Instituto de Biociências, Universidade Estadual Paulista, Botucatu (LBP); Departamento de Zoologia e Botânica, Universidade Estadual Paulista, São José do Rio Preto (DZSJRP); Laboratório de Ictiologia de Ribeirão Preto, Faculdade de Filosofia, Ciências e Letras de Ribeirão Preto, Universidade de São Paulo, Ribeirão Preto (LIRP); Museu de Ciências e Tecnologia, Pontifícia Universidade Católica do Rio Grande do Sul, Porto Alegre (MCP); and Museu Nacional, Universidade Federal do Rio de Janeiro, Rio de Janeiro (MNRJ).

Counts and measurements follow Boeseman (1968), except that body plate counts and nomenclature follow Schaefer (1997). Specimen size is reported as standard length (SL) expressed in $\mathrm{mm}$. All other measurements are expressed as a percentage of standard length, except for subunits of the head, which are expressed as a percentage of head length. Measurements were taken from the left side of the body whenever possible. Specimens were cleared and double stained for bone and cartilage according to the method of Taylor \& Van Dyke (1985).

An analysis of the relative growth was performed to identify the existence of morphological differences among the samples of Pseudotocinclus. This analysis was conducted in two stages: first, the allometric relationships among morphometric variables for fishes from each basin were analyzed through a simple regression analysis and logarithmic transformation of the data using the natural basis $e(\mathrm{Ln})$; thereafter, it was verified if these relationships were distinct among the specimens through a covariance analysis (Zar, 1999). An analysis of canonical variable was employed to verify if the specimens of Pseudotocinclus from the basins of the rio Tietê, rio Ribeira de Iguape, and rio Paraíba do Sul belong to different groups, according to their morphological and meristic characteristics (Manly, 1994; Sokal \& Rohlf, 1995; Hair et al., 1998; Zar, 1999). All statistical tests were conducted at a significance level of 0.05 .

\section{Results}

\section{Pseudotocinclus Nichols, 1919}

Pseudotocinclus Nichols, 1919: 533. Type species: Pseudotocinclus intermedius Nichols, 1919:534, by monotypy. Gender: masculine.

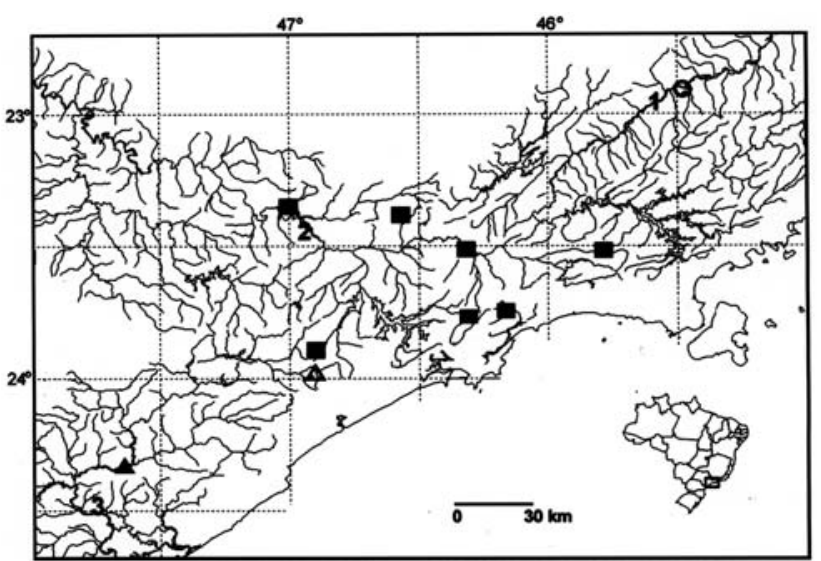

Fig. 1. Southern part of São Paulo, Brazil, showing the geographic distribution of $P$. tietensis (squares), $P$. juquiae (triangles), and $P$. parahybae (circle). Some symbols represent more than one lot or locality. Open symbols = type locality. The precise type locality of $P$. tietensis is not known. 1- rio Paraíba do Sul basin; 2 - rio Tietê basin; 3 - rio Ribeira de Iguape basin.

Diagnosis. The genus Pseudotocinclus can be diagnosed from other Hypoptopomatinae by the presence of a caudal peduncle that is nearly square in cross section from the posterior base of the dorsal fin to the caudal fin, and the following combination of characters: 26 or more plates along the lateral line, a dorsally positioned eye, an exposed preopercle, and an abdomen covered with numerous small platelets.

Description. Dorsal surface of trunk near the dorsal fin forming a depression, which becomes progressively posteriorly flattened near caudal peduncle; ventral surface of trunk between the anal fin and caudal peduncle flattened; dorsal series of plates extending from origin of dorsal-fin to end of caudal peduncle. Mid-dorsal series of plates interrupted; only four to five plates counting from origin of dorsal-fin. Plates of median series dorsally expanded and touching dorsal series of plates. Median series complete. Mid-ventral series of plates interrupted at 17-22 plates, counting from compound pterotic. Ventral series of plates complete, counting from near origin of ventral-fin unbranched ray to end of caudal peduncle; dorsal and ventral series of plates forming distinct longitudinal keels; second nuchal plate large and fused to first proximal radial; first dorsal-fin unbranched ray present; non-functional dorsal-fin locking mechanism. Abdomen entirely covered by numerous platelets; area between pelvic fin and urogenital pore scarcely covered by platelets. Dorsal fin I,7; pectoral fin I,6; ventral fin i,5; anal fin i,5; caudal fin i,14,i. Adipose fin absent. Snout tip naked or covered with small platelets, with odontodes; all teeth bicuspid, inner cusp greater than outer cusp; maxillary barbel present. Major area of scapular bridge covered with skin with platelets, leaving only small ventrolateral portion of coracoid exposed; males with urogenital papilla and dermal flap on entire length of dorsal surface of pelvic-fin unbranched ray; pelvic-flap distinctly higher near 
pelvic-fin base. Proximal tips of first and last pterygiophores of anal fin lying ventral to hemal spines of vertebrae 15 and 19 respectively; total vertebrae 32-33; perforated plates of lateral line 23-32; dark-brown midlateral stripe extending from snout to end of caudal peduncle. Three to four transverse dark-brown bands on dorsal region of body coalesced with midlateral stripe.

Distribution. Species of this genus are found in the upper rio Tietê basin, São Paulo, in the ribeirão Grande, a tributary of the middle course of the rio Paraíba do Sul, Pindamonhangaba, São Paulo, in the headwaters of rio Itatinga, a coastal river of São Paulo, and in the upper and lower courses of the rio Juquiá, rio Ribeira de Iguape basin, São Paulo (Fig. 1).

\section{Key to the species of Pseudotocinclus:}

1. Orbital ring not prominent or conspicuous; parieto-supraoccipital and paired compound pterotic with low crest; parieto-supraoccipital bordered posteriorly by 3-6 large plates

1'. Orbital ring very prominent and conspicuous; parieto-supraoccipital and paired compound pterotic with very high crest; parieto-supraoccipital bordered posteriorly by ten or more small plates . P. juquiae

2. Frontal in contact with compound pterotic at orbital margin, separating sphenotic from orbit margin; snout tip usually covered by small platelets with odontodes

..P. parahybae

2 '. Frontal separated from compound pterotic at orbital margin by sphenotic, which contributes to the orbital margin; snout with small naked area at tip P. tietensis

\section{Pseudotocinclus tietensis (Ihering, 1907)}

Fig. 2

Otocinclus (Microlepidogaster) tietensis Ihering, 1907: 2627 (type-locality: rio Tietê, São Paulo). - Eigenmann, 1910: 413 (reference). - Gosline, 1945: 100 (reference). - Fowler, 1954: 131 (reference). - Britski, 1969: 200 (catalogue of types).

Pseudotocinclus tietensis. - Britski \& Garavello, 1984: 226 (redescription). - Burgess, 1989: 439 (list of the species of Loricariidae). - Montoya-Burgos et al., 1998: 363-374 (phylogenetic relationships of the Loricariidae). - Isbrücker, 2001: 32 (reference). - Schaefer, 2003: 327 (check list).

Microlepidogaster tietensis. - Miranda Ribeiro, 1911: 89, 422 (copy of description).

Pseudotocinclus intermedius Nichols, 1919: 534 (type-locality: Campo Grande, Santo André, São Paulo). - Gosline, 1945: 99 (catalogue). - Fowler, 1954: 134 (reference). Isbrücker, 1980: 86 (classification and catalogue of Loricariidae). - Schaefer, 2003: 327 (check list; as synonym of $P$. tietensis; type locality erroneously assigned as Campo Grande, Mato Grosso).

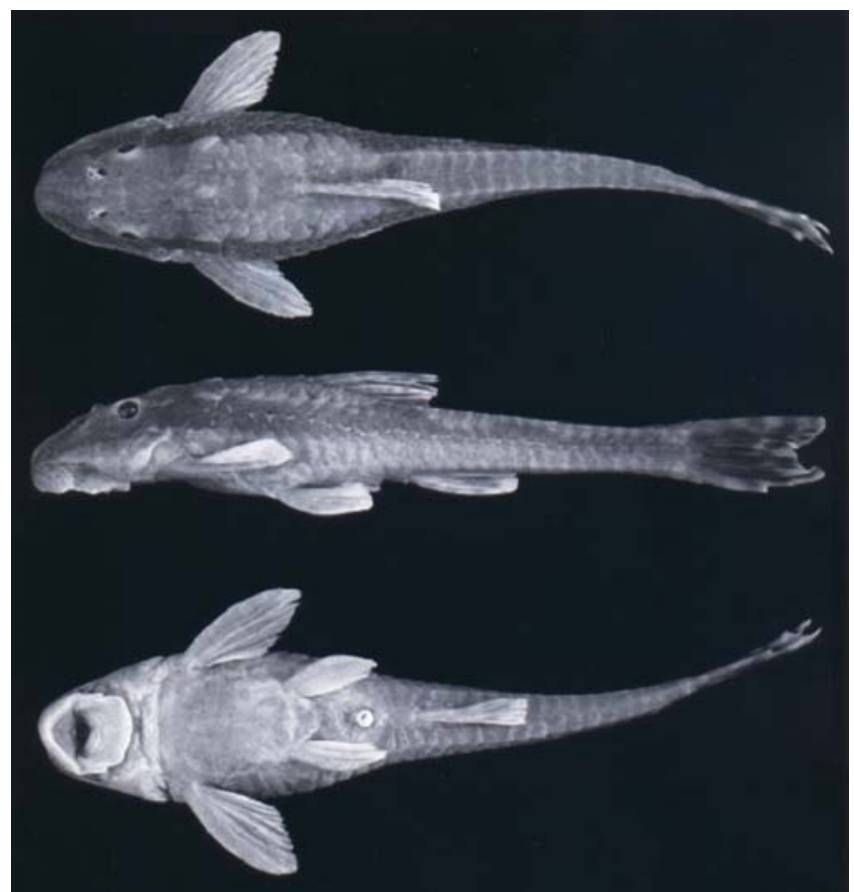

Fig. 2. Pseudotocinclus tietensis, MZUSP 35235, $50.3 \mathrm{~mm}$ SL; small creek near Paranapiacaba, Santo André, São Paulo, Brazil.

Material examined. Brazil, São Paulo: MZUSP 714 (1), $44.0 \mathrm{~mm}$ SL, Alto da Serra, near Paranapiacaba, Santo André (Paratype of Pseudotocinclus intermedius). MZUSP 1003 (1), 46.5 mm SL, Perus (Paratype of Pseudotocinclus intermedius). MZUSP 35235 (8), 37.6-50.3 mm SL, small creek near Paranapiacaba, Santo André, Excursão MZUSP, Nov 1985. MZUSP 42389 (29, 2 c\&s), 31.2$58.7 \mathrm{~mm}$ SL, same locality as above. LIRP 5283 (6), 39.3-58.1 mm SL, same locality as above, 31 Oct 1988. MZUSP 42390 (4), 49.4$57.2 \mathrm{~mm}$ SL, a small creek close to the above locality, 31 Oct 1988. MCP 37522 (4), 47.5-60.8 mm SL, a small creek close to the above locality, 31 Oct 1988. MZUSP 42330 (6), 47.6-55.9 mm SL, Itabim, a tributary of the rio Juqueri Mirim, Companhia Melhoramentos de São Paulo, rio Tietê basin, Caieiras, 22 Nov 1990. LBP 696 (18), 47.7-56.5 mm SL, a tributary of rio Grande, rio Paranapiacaba, rio Tietê basin, approximately $23^{\circ} 46^{\prime}$ S, $46^{\circ} 19^{\prime} \mathrm{W}$, Santo André, 10 Mar 2000. MNRJ 28391 (5), 54.6-57.5 mm SL, rio Paraitinga, rio Tietê basin, Salesópolis, 2331.5'S, 4547.5'W, 24 Jan 2001. MNRJ 28391 (6), 30.8-67.2 mm SL, rio Paraitinga, rio Tietê basin, Salesópolis, $23^{\circ} 31.5^{\prime} \mathrm{S}, 45^{\circ} 47.5^{\prime} \mathrm{W}, 24$ Jan 2001. MZUSP 48127 (2 c\&s), no data. MZUSP 85905 (4), 29.6-35.7 mm SL, rio Lavras, tributary of the rio Tietê, Embu Guaçu, 235'4"'S, 4655'12"W, 30 Aug 2004. DZSJRP 6606 (3), 21.2-31.5 mm SL, rio Itatinga, near Visitors Center, Reserva Particular do Patrimônio Natural Parque das Neblinas, Bertioga, 234' 59"S, 4609'51"W, 27 May 2004. MZUSP 87766 (23), 32.1-57.6 mm SL, creek at the Núcleo Barrocada, Parque Estadual da Cantareira, São Paulo, 2323'09"S, 46³3'56"W, 07 July 2005.

Diagnosis. The presence of a small naked area on the snout tip distinguishes Pseudotocinclus tietensis from P. parahybae and $P$. juquiae, which have the snout tip covered with small platelets. In addition, Pseudotocinclus tietensis has four transverse dark-brown bands on the dorsal region of the body 
that coalesce with a midlateral stripe, rather than three in its congeners.

Description. Morphometric and meristic data given in Table 1; examined specimens 37.6-58.1 mm SL; dorsal profile of head convex from snout tip to end of parieto-supraoccipital; dorsal profile of body convex from snout tip to dorsal-fin origin; relatively straight and gently descending from dorsal-fin origin to end of caudal peduncle; ventral profile of body straight from snout tip to scapular bridge; convex more posteriorly to origin of anal-fin, and straight along caudal peduncle. Head plates with small odontodes and comparatively smooth; median region of snout with low crest that terminates between nares; another low crest on either side of snout that continues as low crest on dorsal region of orbit; orbital ring not as prominent or conspicuous as in $P$. juquiae; parieto-supraoccipital and paired compound pterotic bones with low crest, comparatively larger in $P$. parahybae, but smaller in $P$. juquiae. Parieto-supraoccipital bordered by three to six plates. Interorbital region flattened. Anterior orbital margin positioned approximately midway between snout tip and pterotic posterior process; distance between ventral orbit margin and ventral surface of head slightly greater than twice orbit length; snout tip with small naked area; narrow area of upper lip near snout tip, with scattered platelets having odontodes; length of maxillary barbel comparatively greater than in P. parahybae. Sphenotic ventral margin contributing to orbit, and contacting frontal anteriorly and compound pterotic posteriorly; as consequence, infraorbital canals of cephalic laterosensory system enter infraorbital series via sphenotic; infraorbital 4 not expanded ventrally and not in contact with preopercle; space between these two bones filled with several small plates. Mid-dorsal series of plates interrupted, only five plates counting from dorsal-fin origin. Plates of median series expanded dorsally and contacting dorsal series of plates. Plates in median (lateral) series with lateral system pores. Third lateral line plate reduced in size, as two anterior plates, positioned posterior to rib of sixth centrum, and not covering distal tip of rib. First five plates of midventral series comparatively small; inferior tip of first plate contacting tip of coracoid ventrolateral process, and fifth plate only touching lateropterygium tip; unplated area dorsal to pelvic fin comparatively larger; first three plates of ventral series comparatively smaller with tips touching external side of basipterygium posterior process. Coracoid with small ventrolateral portion exposed and covered with odontodes implanted directly on bone. Abdomen covered with relatively large and roughly rounded platelets not in contact with one another, leaving

Table 1. Morphometric and meristic data for Pseudotocinclus species. Ratios expressed as percent of standard length, head length or interorbital length. For the meristic values the modal number is presented instead of the mean. Hol - holotype.

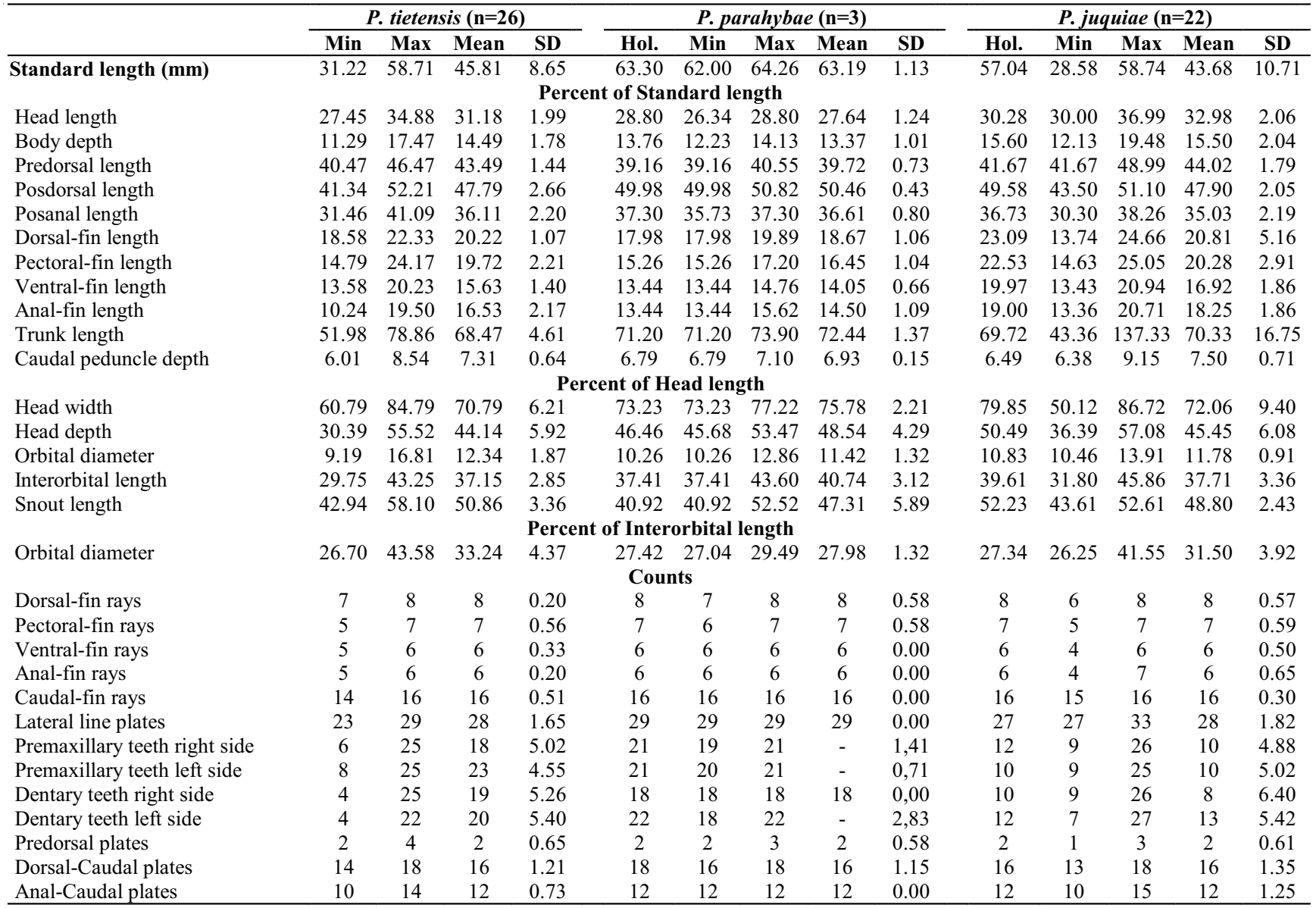


naked area of skin exposed; region between pelvic fin and urogenital pore scarcely covered with platelets. Dorsal-fin origin situated slightly posterior to vertical line through pelvic-fin origin; posterior margin of dorsal fin straight. When depressed, tip of first unbranched dorsal-fin ray reaching vertical line through origin of third ray of anal-fin; first unbranched dorsal-fin ray width greater than width of second unbranched dorsal-fin ray base. Pectoral-fin unbranched ray covered with small odontodes; its tip extending past pelvic-fin origin; length of first branched pectoral-fin ray equal to unbranched pectoral-fin ray. Distal margin of pelvic fin slightly rounded; its tip almost reaching anal-fin origin. Internal and external anterior processes of pelvic-fin basipterygia fused into compact bone. Basal lamina of first proximal radial of anal fin covered with skin and five or six small irregular plates not visible externally. Hemal spine of vertebra 20 bifurcated; caudal fin with four dorsal procurrent rays and three ventral procurrent rays.

Color in alcohol. Light brown ground coloration on dorsal and lateral regions of body; head, ventral region, and belly grayish, with numerous dark brown melanophores distributed on surface; dark brown midlateral stripe extending from snout to end of caudal peduncle; stripe almost equal in width in entire length. Four transverse dark-brown bands on dorsal region of body coalesced with midlateral stripe, first at dorsal-fin origin, second just behind dorsal-fin base, third in middle of caudal peduncle, and last near posterior end of caudal peduncle; second band broader than others. Unbranched and branched caudal-fin rays and interradial membranes sometimes showing uniformly dark brown ground coloration as in P. parahybae or showing color pattern similar to that of P.juquiae; unbranched rays of other fins with four to five dark brown bands; branched rays with bands of melanophores irregularly arranged; interradial membranes hyaline.

Distribution and habitat. This species occurs in many tributaries of the upper Tietê basin (Fig. 1). It is found both in small creeks and medium size rivers such as the rio Paraitinga, a tributary of the rio Tietê, where it lives grazing on semisubmersed overhanging plants; in the rio Grande, a small sized river which drains to the Billings Dam near Vila de Paranapiacaba, Santo André. This species can be found attached to the grass along the river margin and in the middle of the river among rocks and pieces of wood in fast current water. In the rio Grande, Pseudotocinclus tietensis coexists syntopically with Glandulocauda melanogenys, Hyphessobrycon reticulatus, Hollandichthys multifasciatus, Astyanax aff. scabripinnis, Characidium oiticicai, Hisonotus depressicauda, Trichomycterus sp., Gymnotus pantherinus, and Phalloceros caudimaculatus. Pseudotocinclus tietensis also occur with Hyphessobrycon anisitsi, Astyanax altiparanae, Hoplias malabaricus, Phalloceros caudimaculatus, Geophagus brasiliensis, Trichomycterus sp., and Taunaya bifasciata, in the conservation unit of Parque Estadual da Cantareira, a remnant of the Atlantic Forest inside the city of São Paulo.

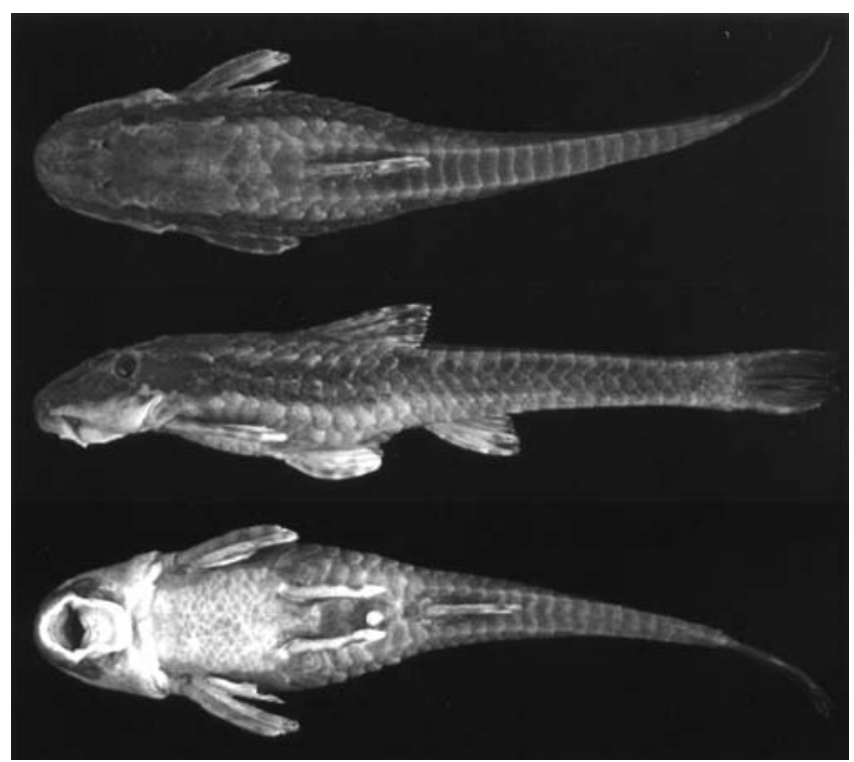

Fig. 3. Pseudotocinclus parahybae, holotype, MZUSP 49122, 62.9 mm SL; tributary of ribeirão Grande, Fazenda São Sebastião do Ribeirão Grande, rio Paraíba do Sul basin, Pindamonhangaba, São Paulo, Brazil.

\section{Pseudotocinclus parahybae, new species}

Fig. 3

Pseudotocinclus tietensis (not of Ihering, 1907). - Bizerril, 1999: 243 (citation of Siluriformes species of Paraíba do Sul basin). - Bizerril \& Lima, 2000:109 (reference, distribution).

Holotype. MZUSP 49122, female, 62.9 mm SL, Brazil, São Paulo, a tributary of the ribeirão Grande, Fazenda São Sebastião do Ribeirão Grande, rio Paraíba do Sul basin, approx. 2246'S, 45²7’W, Pindamonhangaba, C. E. E. Santo, 12 Aug 1995.

Paratypes. MZUSP 47581, 1 c\&s, $62.0 \mathrm{~mm}$ SL, same locality of the holotype; O.T. Oyakawa \& C. Moreira, 31 Mar 1994. MZUSP 83611, female, $66.4 \mathrm{~mm}$ SL, same locality as holotype, C. Oliveira et al., 15 Feb 2001.

Diagnosis. Distinguished from its congeners by having the frontal in contact with the compound pterotic bone, which excludes the sphenotic from the orbit margin ( $v s$. sphenotic ventral margin contributing to the orbit, contacting the frontal anteriorly, and the compound pterotic posteriorly in $P$. tietensis and $P$. juquiae); the abdomen is entirely covered with large platelets that are in each other, leaving no naked skin exposed ( $v s$. abdomen covered with comparatively small and roughly rounded platelets not in contact with each other, leaving naked area of skin exposed); and the region between the pelvic fin and urogenital pore naked (vs. region between pelvic fin and urogenital pore scarcely covered with platelets in P. tietensis and P. juquiae).

Description. Morphometric and meristic data given in Table 1; examined specimens 62.0-66.4 mm SL; dorsal profile of head 
convex from snout tip to orbital ring; relatively straight from this point to end of parieto-supraoccipital; dorsal profile of trunk straight and gently descending from parieto-supraoccipital to end of caudal peduncle; ventral profile of body gently straight from snout tip to scapular bridge; convex from this point to origin of anal fin, and straight from this point to caudal-fin origin. Head plates with small odontodes and comparatively smooth; median region of snout with low crest that finishes between nares; another low crest on either side of snout that continues in low crest on dorsal region of orbit; orbital ring not as prominent or conspicuous as in P. juquiae. Parieto-supraoccipital and paired compound pterotic bones with low crest. Parieto-supraoccipital crests broader than compound pterotic ones. Posteriorly, parieto-supraoccipital bordered by three to four large plates. Interorbital region flattened. Anterior orbit margin positioned approximately midway between snout tip and pterotic posterior process; distance between ventral orbit margin and ventral surface of head approximately twice as long as orbit length. Snout tip usually covered with small platelets, which have odontodes; narrow area of upper lip near tip of snout, usually with platelets with odontodes. Length of maxillary barbel comparatively smaller than in P. tietensis. Frontal contacting anterior margin of compound pterotic isolating sphenotic from orbit. As consequence, infraorbital canals of cephalic laterosensory system enter infraorbital series via frontal compound pterotic junction. Infraorbital 4 greatly expanded ventrally and contacting preopercle. Mid-dorsal series of plates interrupted, only five plates counting from dorsal-fin origin. Plates of median series dorsally expanded and touching dorsal series of plates. Plates in median (lateral) series with lateral line system pore; third lateral line plate large and nearly completely covering expanded distal tip of rib on sixth centrum. First two canal plates reduced in size; first five plates of midventral series comparatively larger; inferior tip of first plate surpassing tip of coracoid ventrolateral process. Fifth plate touching external side of basipterygium and totally covering lateropterygium; unplated area above pelvic fin comparatively smaller; first three plates of ventral series comparatively larger, and totally covering basipterygium posterior process. Coracoid with only small ventrolateral portion exposed and covered with odontodes implanted directly on bone. Abdomen entirely covered with comparatively large platelets contacting one another, leaving no naked area of skin exposed; region between pelvic-fin and urogenital pore naked. Dorsalfin origin situated slightly posterior to vertical line through pelvic-fin origin; posterior margin of dorsal fin straight. When depressed, tip of dorsal-fin unbranched ray reaching vertical line through origin of third ray of anal-fin ray; first dorsal-fin unbranched ray width greater than width of second dorsalfin unbranched ray base; pectoral-fin unbranched ray covered with small odontodes; its tip reaching of pelvic-fin origin; length of first pectoral-fin ray equal to length of pectoralfin unbranched ray. Posterior margin of pelvic fin slightly rounded; its tip reaching anus. Internal and external anterior processes of pelvic-fin basipterygia fused in compact bone.
Basal lamina of first proximal radial of anal fin greatly expanded, not covered with plates and completely visible externally; visible part being rounded in shape; hemal spines of vertebrae 15-20 non-bifurcated; caudal fin with four dorsal procurrent rays and four ventral procurrent rays.

Color in alcohol. Light brown ground coloration on dorsal and lateral region of body; ventral region of head and belly grayish with numerous dark-brown melanophores distributed randomly. One comparatively broad dark brown midlateral stripe extending from snout to end of caudal peduncle; stripe more conspicuous anteriorly, becoming progressively faded on caudal peduncle. Three, sometimes indistinct, transverse, dark-brown bands on dorsal region of body coalesced with midlateral stripe, first just behind dorsal-fin base, second in middle of caudal peduncle, and last at end of caudal peduncle. Unbranched and branched caudal-fin rays and interradial membranes uniformly dark-brown ground coloration with numerous small melanophores; unbranched rays of other fins with three to five dark brown bands; branched rays with bands of melanophores irregularly arranged; interradial membranes hyaline.

Distribution and habitat. This species is known only from the type-locality, a tributary of the ribeirão Grande, rio Paraíba do Sul basin (Fig. 1). The type-locality is a medium-size creek, 0.5 $\mathrm{m}$ to $1.5 \mathrm{~m}$ deep and $5.0 \mathrm{~m}$ wide at approximately 800 meters above sea level, on the slope of Serra da Mantiqueira, with very clear, well oxygenated, and fast flowing water, running mainly on stone beds. The following species occur with Pseudotocinclus parahybae at type-locality: Astyanax bimaculatus, Astyanax intermedius, Characidium sp., Rhamdia quelen, Imparfinis minutus, Taunayia bifasciata, Trichomycterus sp., Harttia carvalhoi, and Neoplecostomus microps.

Etymology. The specific epithet, parahybae, from the Tupi Language [pa'ra] plus [a' yba], "paraíba" in Portuguese, meaning a useless river, or a portion of river too difficult to navigate, and refers to the name of the river basin where this species had been collected. Treated as a noun in apposition.

\section{Pseudotocinclus juquiae, new species}

Fig. 4

Pseudotocinclus tietensis (not of Ihering, 1907). - Bizerril \& Lima, 2000:109 (reference, distribution).

Holotype. MZUSP 49333, male, 57.0 mm SL, Brazil, São Paulo, first tributary of the rio Juquiá, near ribeirão das Antas on the road from São Lourenço da Serra to Juquitiba, 2359'49.1 "S, $46^{\circ} 56^{\prime} 01.0$ 'W, Juquitiba, O. T. Oyakawa \& A. Akama, 20 Jan 1996.

Paratypes. Brazil, São Paulo: MZUSP 42040 (1), 31.7 mm SL, ribeirão Poço Grande, a tributary of the rio Juquiá, $25^{\circ} 15^{\prime} 14.8$ “S, 47³7’12.6" W, Juquiá, A. A. Andreata \& C. Oliveira, 5 May 1989. MZUSP 49339 (1), 28.5 mm SL, ribeirão das Antas, a tributary of the rio Juquiá, at Fazenda Estio, on the road 
from São Lourenço da Serra to Juquitiba, $23^{\circ} 55^{\prime} \mathrm{S}, 46^{\circ} 55^{\prime} \mathrm{W}$, Juquitiba, O.T. Oyakawa \& A. Akama, 20 Jan 1996. MZUSP 79047 (2), 48.5-55.9 mm SL; collected with the holotype. MZUSP 58805 (3), 33.7-56.3 mm SL; same locality as the holotype; O. T. Oyakawa, A. Akama \& F. C. Lima, 25 Oct 1999. MZUSP 79048 (2), 57.1-60.2 mm SL; same locality as the holotype; Projeto Biota/Fapesp Ribeira, 26 Jun 2002. MZUSP 58816 (2) (2 c\&s), 53.7-57.5 mm SL; same locality as the holotype; O. T. Oyakawa, A. Akama \& F. C. Lima, 8 Nov 1999.

Non-type material. Brasil, São Paulo: LBP 616 (13), 28.9-58.7 $\mathrm{mm}$ SL, same locality as the holotype, 8 Nov 1999. LBP 1160 (6), 32.1-62.2 mm SL; same locality as the holotype, 30 Apr 2001.

Diagnosis. Distinguished from its congeners by having the orbital ring very prominent and conspicuous (vs. orbital ring not prominent or conspicuous in P. tietensis and P. parahybae); the parieto-supraoccipital and paired compound pterotic bones with a very high crest ( $v s$. parieto-supraoccipital and paired compound pterotic bones with a low crest); the parieto-supraoccipital bordered posteriorly by ten or more small plates (vs. parieto-supraoccipital bordered by three to four large plates in $P$. parahybae, and three to six large plates in P. tietensis); and the exposed portion of the cleithrum and coracoid comparatively smaller than in $P$. parahybae and $P$. tietensis.

Description. Morphometric and meristic data given in Table 1; examined specimens 28.5-62.2 mm SL; dorsal profile of head convex from snout tip to orbital ring; relatively straight from

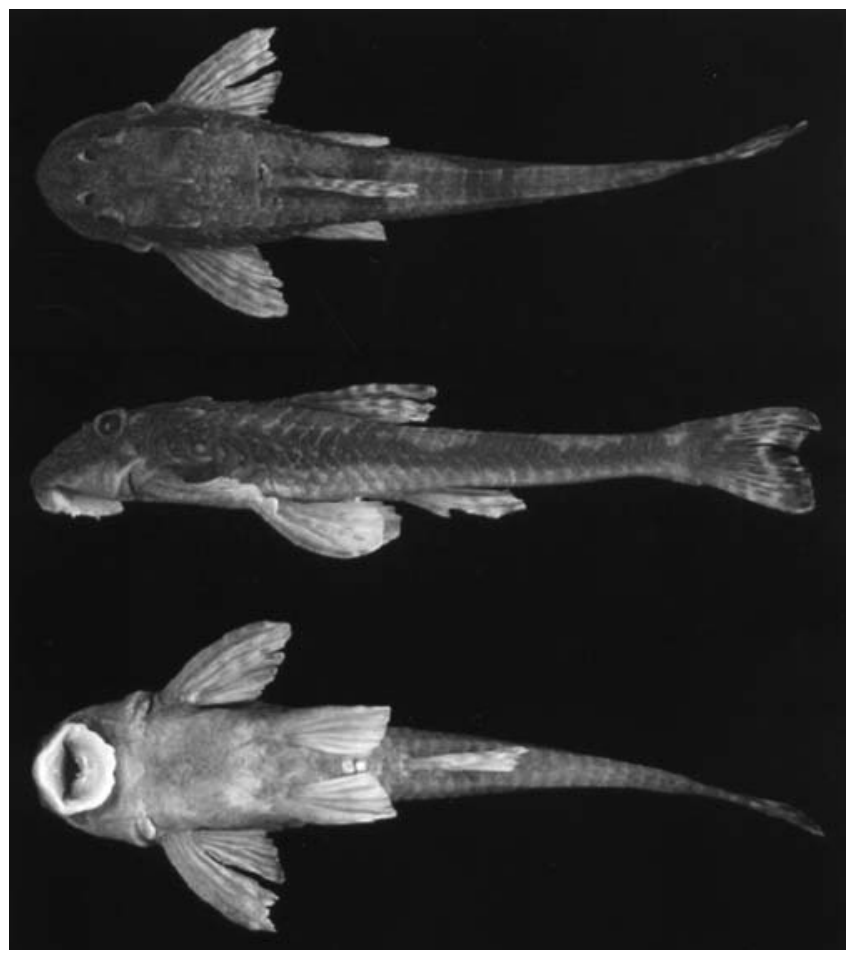

Fig. 4. Pseudotocinclus juquiae, holotype, MZUSP 49333, $57.04 \mathrm{~mm}$ SL; first tributary of the rio Juquiá, near ribeirão das Antas on the road from São Lourenço da Serra to Juquitiba, Juquitiba, São Paulo, Brazil. this point to end of parieto-supraoccipital; dorsal profile of trunk straight and gently descending from parieto-supraoccipital to end of caudal peduncle; ventral profile of body gently straight from snout tip to end of caudal peduncle. All plates of head with small odontodes and comparatively rugged; median region of snout with low crest that finishes between nares, which are surrounded posteriorly by low crest, more noticeable in adults males; another low crest on either side of snout, that continues in very high crest on dorsal region of orbit; orbital ring very prominent and conspicuous; parieto-supraoccipital and paired compound pterotic bones with very high crest. Compound pterotic crest continuing in one keel up to plates located near midway of dorsal-fin base. Posteriorly, parieto-supraoccipital is bordered by ten or more small plates; interorbital region slightly concave. Anterior orbit margin positioned approximately midway between snout tip and pterotic posterior process; distance between ventral orbit margin and ventral surface of head greater than twice orbit length. Snout tip entirely covered with small platelets with odontodes; sometimes leaving small naked area. Narrow area of upper lip, near tip of snout, with platelets with odontodes. Length of maxillary barbel proportionally greater than in $P$. parahybae. Sphenotic ventral margin contributing to orbit and contacting frontal anteriorly and compound pterotic posteriorly; as consequence, infraorbital canals of cephalic laterosensory system enter infraorbital series via sphenotic. Infraorbital 4 not expanded ventrally and not contacting preopercle; space between these two bones filled with several small plates. Mid-dorsal series of plates interrupted, only five plates counting from dorsal-fin origin. Dorsal series of plates ventrally expanded, and touching median series of plates. Plates in median (lateral) series with lateral line system pore; third lateral line plate reduced in size, as other two anterior plates, and positioned posterior to rib of sixth centrum, and not covering distal tip of rib. First five plates of midventral series comparatively small; inferior tip of first plate contacting tip of coracoid ventrolateral process, fifth plate only touching lateropterygium tip; unplated area above pelvic fin comparatively large. First three plates of ventral series comparatively small; their tips touching external side of basipterygium posterior process. Coracoid with only small ventrolateral portion exposed and covered with odontodes implanted directly on bone; exposed portion of cleithrum and coracoid comparatively smaller than in $P$. parahybae and P. tietensis. Abdomen covered with comparatively small and roughly rounded platelets not in contact with each other, leaving naked area of skin exposed; region between pelvic-fin and urogenital pore scarcely covered with platelets; dorsal-fin origin situated slightly posterior to vertical line through pelvic-fin origin; posterior margin of dorsal fin straight. When depressed, tip of second unbranched dorsal-fin ray reaching vertical line through second or third anal-fin ray. First unbranched dorsal-fin ray width equals width of second dorsal-fin ray; unbranched pectoral-fin ray covered with small odontodes; its tip extending slightly beyond pelvic-fin origin; length of first branched pectoral-fin ray equal to pectoral-fin unbranched 
ray length. Posterior margin of pelvic fin slightly rounded; its tip surpassing anus. In adult males, tip of unbranched pelvicfin ray reaches origin of anal fin; internal and external anterior processes of pelvic-fin basypterigyum growing independently forward, and connected anteriorly delimiting one large foramen; basal lamina of first proximal radial of anal fin greatly expanded, covered with skin and sometimes with small rounded plates covered with odontodes; and not visible externally; hemal spines of vertebrae 16 and 17 with small bifurcated process that becomes progressively larger in vertebrae 18-20; caudal fin with five dorsal procurrent rays and four ventral procurrent rays.

Color in alcohol. Light-brown ground coloration on dorsal, lateral and ventral regions of body; these regions spotted by numerous dark brown melanophores distributed randomly, and more concentrated just below lower lips; one dark brown midlateral stripe extending from snout to end of caudal peduncle; stripe larger anteriorly, becoming progressively narrower on caudal peduncle. Three transverse dark brown bands on dorsal region of body coalesced with midlateral stripe, first just behind dorsal-fin base, second in middle of caudal peduncle, and last in end of caudal peduncle; second band broader than first and third. Unbranched caudal-fin rays with four to five dark brown blotches; branched rays with bands of melanophores irregularly arranged forming reticulated pattern, or sometimes arranged in two near-vertical bands; interradial membranes hyaline; unbranched rays of other fins with four to five dark brown bands; branched rays with bands of melanophores irregularly arranged; interradial membranes hyaline.

Distribution and habitat. This species is known from a few localities of the rio Juquiá basin (Fig. 1). The type-locality, Juquitiba, is a small creek $0.5 \mathrm{~m}$ to $1.0 \mathrm{~m}$ deep, $1.0 \mathrm{~m}$ wide at approximately 670 meters above sea level. It is clear, with a slow current, mud, and in some places, sand on the bottom. Marginal vegetation includes a small area of pastures, small trees and shrubs. The following species occur with Pseudotocinclus juquiae at the type-locality: Hyphessobrycon bifasciatus, Hyphessobrycon reticulatus, Characidium schubarti, Characidium pterostictum, Hoplias malabaricus, Gymnotus pantherinus, Geophagus brasiliensis, and Phalloceros caudimaculatus. The other locality is the ribeirão Poço Grande, a tributary on the right margin of the rio Juquiá , Juquiá. This locality, an old swamp area near the city of Juquiá, was a site where a team from MZUSP has been collecting since 1897. Nowadays, the area is heavily impacted by human activities, and is also used for garbage and sewage disposal. The following species occur syntopically with Pseudotocinclus juquiae at ribeirão Poço Grande: Astyanax ribeirae, Mimagoniates microlepis, Rineloricaria sp., Parotocinclus maculicauda, Pseudotothyris obtusa, Rhamdia quelen, Gymnotus pantherinus, Rivulus santensis, and Microcambeva ribeirae.

Etymology. The specific epithet, juquiae, from Tupi Language "yeke'a", "juquia" or "jequiá" in Portuguese, means a small fishing device used in shallow water, and refers to the name of the river basin where this species had been collected. Treated as a noun in apposition.

\section{Discussion}

Since the sample of Pseudotocinclus parahybae is composed of only three specimens, regression lines for these specimens were not significant ( $\mathrm{p}>0.05$ ). On the other hand, all other lines obtained in the comparison with $P$. tietensis and $P$. juquiae, respectively, were highly significant $(\mathrm{p}<0.0001)$. The $F$ test for the linear coefficient showed that $P$. juquiae had dorsal-fin length, anal-fin length, and ventral-fin length proportionally longer than those found in P. tietensis (Figs. $5 \mathrm{a}-\mathrm{c})$. On the other hand, $P$. tietensis had the trunk length proportionally longer than that found in P. juquiae (Fig. 5d). The $F$ test for angular coefficient (parallelism) showed that the specific rate of growth of the dorsal-fin length in relation with the standard length was higher in $P$. juquiae than that found in P. tietensis, but the specific rate of growth of the trunk length in relation with the standard length was higher in P. tietensis than in P. juquiae.

The results obtained in the analysis of the canonical variables is shown in Fig. 6. Among all morphometric and meristic variables analyzed, the discriminative analysis chose the following in the stepwise process: standard length (SL)/dorsalfin length (DFL), SL/predorsal length (PL), interorbital distance (IOD)/orbital distance (OD), SL/pectoral-fin length (PFL), SL/head depth (HD), SL/head length (HL), SL/ventral-fin length (VFL), SL/snout length (SNL), number of dorsal-fin rays, SL/PAL, number of predorsal plates (PDP), and SL/analfin length (AFL). The other variables investigated were maintained out of the model studied. Three groups were formed P. juquiae, P. tietensis and $P$. parahybae - with some overlap among the specimens of $P$. juquiae and $P$. tietensis. The first canonical function separated $P$. parahybae from $P$. juquiae + $P$. tietensis. The second canonical function separated $P$. juquiae and $P$. tietensis. The canonical analysis shows that the discriminative function 1 is more positively correlated with SL/DFL, SL/PL, SL/PFL, SL/HL, SL/VFL, and SL/AFL and the discriminative function 2 is more positively correlated with SL/DFL, SL/VFL and SL/AFL (correlations higher than 0.20). Thus, P. parahybae is more elongate (larger standard length in relation to the other morphometric variables) when compared with $P$. tietensis and P. juquiae.

The headwaters of the rio Tietê, rio Paraíba do Sul, and rio Juquiá are located very close to each other near the city of São Paulo. Geological studies suggested that tributaries of the rio Paraíba do Sul basin and of the rio Tietê basin were connected until the Miocene [23 to 8 million years ago (Myr)] when they were separated (Malabarba, 1998). However, considering the modern aspect of the paleoflora and mainly of that from the aquatic paleofauna, some paleontologists suggested that this separation could have been more recent (about 1.5 Myr) (Travassos \& Santos, 1955; Duarte \& Japiassú, 1971; Brito \& Ribeiro, 1975). Geological studies 

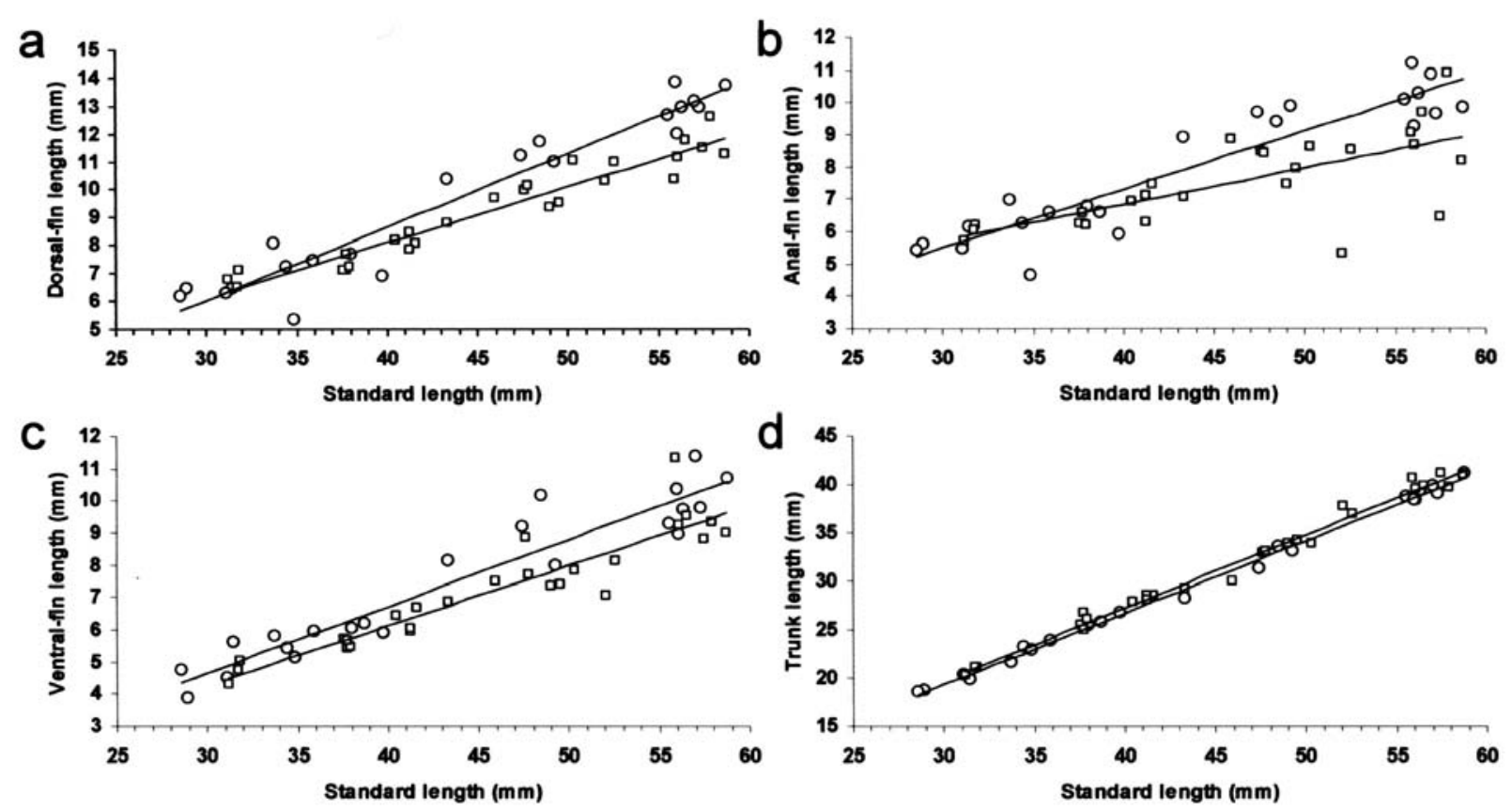

Fig. 5. Biplots showing the distribution of data obtained for specimens of Pseudotocinclus juquiae (circles) and P. tietensis (squares).

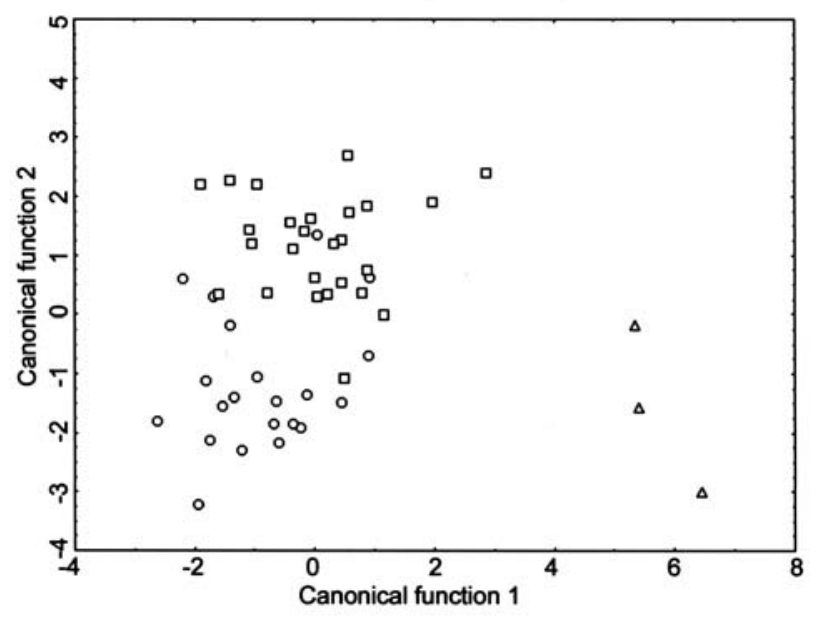

Fig. 6. Results of the canonical variable analyses comparing Pseudotocinclus juquiae (circles), P. tietensis (squares), and P. parahybae (triangles).

showed that the Ribeira de Iguape extended its drainage south by the capture of some old tributaries of the rio Iguaçu, north of Curitiba, and extended its drainage north by the capture of some old tributaries of the rio Tietê , south of Embu-Guaçu (Almeida \& Carneiro, 1998). The capture of the rio Tietê tributaries by the Ribeira de Iguape was not dated (Almeida \& Carneiro, 1998). However, some evidence suggests that this capture could have occurred during the Miocene (Melo et al., 1989) or even more recently (Riccomini et al., 1989). The occurrence of different species of Pseudotocinclus in the rio Tietê, rio Paraíba do Sul, and rio Ribeira de Iguape basins corroborate the hypothesis that these three basins were connected in the past. Our preliminary phylogenetic studies indicate that $P$. parahybae may be the sister-group of $P$. tietensis plus $P$. juquiae thus, the capture of the rio Tietê tributaries by the Ribeira de Iguape should be more recent than the separation of the drainages of rio Tietê and rio Paraíba do Sul.

\section{Acknowledgements}

A previous version of this work was a dissertation submitted by the senior author in partial fulfillment of a Master's degree in Zoology, at Instituto de Biociências de Botucatu Universidade Estadual Paulista. Laboratório de Biologia e Genética de Peixes (LBP) - Instituto de Biociências de Botucatu - Universidade Estadual Paulista, Museu de Zoologia Universidade de São Paulo (MZUSP), and Laboratório de Ictiologia de Ribeirão Preto (LIRP) - Departamento de Biologia da Faculdade de Filosofia, Ciências e Letras de Ribeirão Preto - Universidade de São Paulo, provided work space and access to all kind of facilities. We are grateful to Roberto E. Reis, Luiz A. C. Bertollo, Marcelo Britto and Alexandre Ribeiro for their critical review of the original manuscript; Renato Devidé and Anderson L. Alves for the collection of Pseudotocinclus; José Nolasco for the photos; Roberto Leung for his technical assistance with the statistical analyses; Alexandre Ribeiro and Eduardo Baena for plotting and editing the map. Field work was supported by FAPESP (Fundação de Amparo à Pesquisa do Estado de São Paulo) within the Thematic Project "Filogenia e evolução de Loricarioidea: uma abordagem multidisciplinar" (FAPESP Grant number: 01/ 11175-9), granted to Claudio Oliveira; "BIOTA/FAPESP - The Virtual Biodiversity Institute Program" (see www.biotasp.org.br), through the Project "Diversidade de peixes de riachos e cabeceiras da Bacia do rio Ribeira de Iguape no Estado de São Paulo" (FAPESP Grant number: 00/04300-9), granted to Osvaldo T. Oyakawa, and the PRONEX Project "Conheci- 
mento, Conservação e Utilização Racional da Diversidade da Fauna de Peixes do Brasil" (FINEP/CNPq Grant number 661058/ 1997-2), granted to Naércio A. Menezes.

\section{Literature Cited}

Almeida, F. F. M. \& C. D. R. Carneiro. 1998. Origem e evolução da Serra do Mar. Revista Brasileira de Geociências, 28: 135-150.

Bizerril, C. R. S. F. 1999. A ictiofauna da Bacia do Rio Paraíba do Sul. Biodiversidade e Padrões Biogeográficos. Brazilian Archives of Biology and Technology, 42: 233-250.

Bizerril, C. R. S. F. \& N. R. W. Lima. 2000. Levantamento da ictiofauna da Bacia do rio Ribeira. Acta Biologica Leopoldensia, 22: 103-110.

Boeseman, M. 1968. The genus Hypostomus Lacépède, 1803, and its Surinam representatives (Siluriformes, Loricariidae). Zoologische Verhandelingen, 99: 1-89.

Brito, I. M. \& F. A. M. Ribeiro. 1975. Ocorrência de lepidópteros nos folhetos de Tremembé e algumas considerações sobre a Bacia Geológica do Paraíba, Estado de São Paulo. Anais da Academia Brasileira de Ciências, 47: 105-111.

Britski, H. A. 1969.Lista dos tipos de peixes das coleções do Departamento de Zoologia da Secretaria da Agricultura de São Paulo. Papéis Avulsos de Zoologia, 22(19): 197-215.

Britski, H. A. \& J. C. Garavello. 1984. Two new southeastern Brazilian genera of Hypoptopomatinae and a redescription of Pseudotocinclus Nichols, 1919 (Ostariophysi, Loricariidae). Papéis Avulsos de Zoologia, 35(21): 225-241.

Burgess, W. E. 1989. An Atlas of Freshwater and Marine Catfishes. A Preliminary Survey of Siluriformes. Tropical Fish Hobbyist, New Jersey. 784p.

Duarte, L. \& A. M. S. Japiassú. 1971. Vegetais Meso e Cenozóicos do Brasil. Anais da Academia Brasileira de Ciências, 43: 433-443.

Eigenmann, C. H. 1910. Catalogue of freshwater fishes of tropical and South Temperate America. Reports of the Princeton University Expeditions to Patagonia, 1896-1899, 3:375-511.

Fowler, H. W. 1954. Os peixes de água doce do Brasil. Arquivos de Zoologia, 9: 1-400.

Gosline, W. A. 1945. Catálogo dos nematognatos de água doce da América do Sul e Central. Boletim Museu Nacional, Zoologia, 33: 1-138.

Hair Jr., J. F., R. E. Anderson, R. L. Tatham \& W. C. Black. 1998. Multivariate Data Analysis. Prentice Hall, Upper Saddle River. 730p.

Ihering, R. von. 1907. Diversas espécies novas de peixes nematognathas do Brasil. Notas Preliminares do Museu Paulista, 1: 13-39.

Isbrücker, I. J. H. 1980. Classification and catalogue of the mailed Loricariidae (Pisces, Siluriformes). Verslagen en Technische Gegevens, 22: 1-181.

Isbrücker, I. J. H. 2001. Nomenklator der Gattungen und Arten der Harnischwelse, Familie Loricariidae Rafinesque, 1815 (Teleostei, Ostariophysi). Datz Harnischwelse, 2: 25-32.

Malabarba, M. C. S. L. 1998. Phylogeny of fossil Characiformes and paleobiogeography of the Tremembé formation, São Paulo, Brazil. Pp. 67-84. In: Malabarba, L. R., R. E. Reis, R. P. Vari, Z. M. S. Lucena \& C. A. S. Lucena (Eds.). Phylogeny and Classification of Neotropical Fishes. Edipucrs, Porto Alegre. 603p.

Manly, B. F. J. 1994. Multivariate Statistical Methods. Chapman and Hall, London. 215p.

Melo, M. S., L. A. Fernandes, A. M. Coimbra \& R. G. M. Ramos. 1989. O gráben (Terciário?) de Sete Barras, Vale do Ribeira de Iguape, SP. Revista Brasileira de Geociências, 19: 260-262.

Miranda Ribeiro, A. 1911. Fauna Brasiliense. Peixes. Tomo IV (A). Eleutherobranchios Aspirophoros. Arquivos do Museu Nacional, 16: 1-504.

Montoya-Burgos, J.-I., S. Muller, C. Weber \& J. Pawlowski, 1998. Phylogenetic relationships of the Loricariidae (Siluriformes) based on mitochondrial rRNA gene sequences. Pp. 363-374. In: Malabarba, L. R., R. E. Reis, R. P. Vari, Z. M. S. Lucena \& C. A. S. Lucena (Eds.). Phylogeny and Classification of Neotropical Fishes. Edipucrs, Porto Alegre. 603p.

Nichols, J. T. 1919. Um novo gênero de cascudos da família Loricariidae. Revista do Museu Paulista, 11: 533-535.

Riccomini, C., A. U. G. Pellogia, J. C. L. Saloni, M. W. Kohnke \& R. M. Figueira. 1989. Neotectonic activity in the Serra do Mar rift system (southeastern Brazil). Journal of South American Earth Sciences, 2: 191-197.

Schaefer, S. A. 1991. Phylogenetic analysis of the loricariid subfamily Hypoptopomatinae (Pisces: Siluroidei: Loricariidae), with comments on generic diagnoses and geographic distribution. Zoological Journal of the Linnean Society, 102: 1-41.

Schaefer, S. A. 1997. The neotropical cascudinhos: systematics and biogeography of the Otocinclus catfishes (Siluriformes: Loricariidae). Proceedings of Academy of Natural Science Philadelphia, 148: 1-120.

Schaefer, S. A. 1998. Conflict and resolution impact of new taxa on phylogenetic studies of the Neotropical cascudinhos (Siluroidei: Loricariidae). Pp. 375-400 In: Malabarba, L. R., R. E. Reis, R. P. Vari, Z. M. S. Lucena \& C. A. S. Lucena (Eds.). Phylogeny and Classification of Neotropical Fishes. Edipucrs, Porto Alegre. 603p.

Schaefer, S. A. 2003. Hypoptopomatinae. Pp. 321-329 In: Reis, R. E., S. O. Kullander \& C. J. Ferraris, Jr. (Eds.). Check list of the freshwater fishes of South and Central America. Edipucrs, Porto Alegre. 729p.

Sokal, R. R. \& F. J. Rohlf. 1995. Biometry. W. H. Freeman, New York. $887 \mathrm{p}$.

Taylor, W. R. \& G. C. Van Dyke. 1985. Revised procedures for staining and clearing small fishes and other vertebrates for bone and cartilage study. Cybium, 9: 107-119.

Travassos, H. \& R. S. Santos. 1955. Caracídeos fósseis da Bacia do Paraíba. Anais da Academia Brasileira de Ciências, 27: 297-322.

Zar, J. H. 1999. Biostatistical Analysis. Prentice-Hall, Upper Saddle River. 930p.

Received July, 2005 Accepted November, 2005 